\title{
L. On the utility of making family wines from several of our garden fruils, especially for benevolent uses. extracted from an address, on different topics, to the board of superintendence of the bath and west of England society
}

\section{W. Matthews}

To cite this article: W. Matthews (1807) L. On the utility of making family wines from several of our garden fruils, especially for benevolent uses. extracted from an address, on different topics, to the board of superintendence of the bath and west of England society, Philosophical Magazine Series 1, 27:108, 290-298, DOI: 10.1080/14786440708563603

To link to this article: http://dx.doi.org/10.1080/14786440708563603

\section{9.}

\section{Submit your article to this journal 둔}

Џll Article views: 4 


\section{[ 290 ]}

L. On the Utility of making Family Wines from several of our Garden Fruils, especially for lenevolent Uses. Extracted from an Address, on different Topics, to the Board of Superintendence of the Bath and West of England Society. By W. Matthews*.

I will now beg to be indulged with your attention to another subject, which some circumstances of the times have led me to reflect on. I mean the present enormous price of foreign wines. It may possibly occur to some of you, that this subject, however serious in a national point of view, is not amiongr those which such a society as ours can hope to take up with success; and even, that it is not among those subjects most properly cognizable by our institution; that foreign wines may be considered, which frequently has bcen the case by the legislature, as an article of luxury, but little connected with the comfort of the great body of the people. To these possible objcctions I am prepared in part to assent; and I would not lightly ask attention to a subject of doubtful propriety. But my views are not directed to wine as a luxury, or to an interference with the taste and habits of persons of sufficient wealth to afford the prices which are now paid for the different kinds of foreign wine. From all present appearance, a sufficient number of those persons will be found to purchase whatever may be importable from the foreign markets, at whatever shall be the curcent prices. I propose to consider the real use of wholesome wine for medicinal purposes, and those of general comfort, frugally used among the injdde and lower ranks of the community. It is allowed, and justly, that for the laborions classes the refresiment of sound malt liquor is the common article of the country; and that no substitute for that, or the wholesome unadulterated cider of some districts, is either to be expected or prudently sought for. But it is to be considered that there are innumerable cases in which some refreshing vinous liquor, different from these, is frequently desirable, for the comfort of persons in delicate situations and states of health, who cannot afford the expense of even a very little foreign wine;

* From Letters and Papers of the Bath and Hist of England Socicty, vol. $x$. 
many of whom, from motives of what they deem oconomy, have recourse to the use of different kinds of spirits, too often, indeed, in large quantities; but among the more cautious, even the smaller ones, though diluted with water, are commonly injurious, It is also obvious that the beginning of this habit of using spirits is too commonly delusive in a large degrec, and insensibly leads on to strong and confirmed habits of pernicious drinking, especially in towns and cities. The mischief to health and morals is well known to be incalculable. The wines commonly sold under the name of British sweets, and which formerly used to be resorted to in cases of sickness and weak health, are now bccome so expensive, that even their aid is generally beyond the reach of the poor; and it seem's probable that the consumption is chiefly by adulteration of foregn white wincs, affording a lucrative trade, by mixture, for tavern consumption, and partly also, in a like mixed state, for private families. Thus the revenue is considerably diminished by the deception. This last, though not an immediate object of our concern, may be allowed its weight in favour of what we wish to propose, as very desirable in itself, and but in a small degree doubtful with regard to the revenue, i. e. the increased manufacture of family wine from the best of our own fruits. What these are, or may by management be, is the next question. To the red ard white currant, commonly uscd, there seems an objection, on account of the acid quality from which their juice is almost inseparable, except by long keeping ; and I cannot but look with much more contidence towards the black currant, the abundant juices and salutary virtues of which seem to have been too little known. Indeed, as an article for wine, few persons scem to have regarded it, though perhaps it will be fisund to be one of our best garden fruits for the purpose in question. There is in this fruit a richness beyond the common estimate; and its flavour, thongh to some palates unpleasant when caten in its recent state, is found to lose much of its characteristic roughness and flavour, when judiciously made into wine, and kept to a moderate age. I am confirmed in this statement by sufficient authority; and perhaps in many cases of sickness, T 3 
as well as for more common use, it has salutary properties, which render it more valuable than the public are generally aware of. The black currant tree is known to be hardy, and in our climate an abundant bearer, by the common mode of garden propagation. But it is well worthy of trial, whether it may not be trained against the walls of the garden, and the sunny sides of houses and coltages, with still greater success. From the best accounts I can get, this seems highly probable; and if so, such abundant propagation may be at once easy, and largely beneficial for our purpose. That such has not been the general practice, is no good reason why, under strong recommendation, it should not becoine so ; and recommendation of useful things, in all the departments of culture, is certainly one of the proper provinces of this comprehensive society. The best mode of making such wine may be nore commonly known than practised; and at any rate it is as easy as any similar process. I threfore feel much confidence of utility from our recommending this domestic object. Another fruit presents itself to our notice, which, in all countries famed for its wines, is of proverbial excellence, i.e. the grape. I am aware that it is a common opinion that our climate is in general too cold and precarious for, the full ripening of the grape; and that vineyards, which in various places have been attempted, have not succeeded so as to answer the cost and labour of vintage. I am persuaded that few are the situations in this island where success may be expected in open-field culture. That object, therefore, I cannot think of recommending. But experience, and some considerable observation, have cunvinced me that much greater success may be expected than many persons are aware of, in cultivating the vine in our warmest districts against the southern walls of numerous farm-houses, country cottages, and even in the small gardens of many towns and cities, where the soil is light and favourable, and that with very easy attention. In cold lands and bleak exposures it would be a fruitless attempt, and common reflection would point out the absurdity. But in some parts of the county of Essex, though less favourable to its success than in other spots of our island, 
island, particularly in Devon and Cornwall, I have known vines so abundantly and successfully wall-trained, as to produce, for private families, an ample supply of most pleasant and valuable wine. Indeed the practice is so common among the coltagers and others inhabiting houses built of brick, that at the ripening season many poor and middling people are in the habit of selling large quantities of grapes, at very reasonable prices, to thieir more wealthy neighbours, for the purpose of making wine. And it is not easily conceivable, by strangers to the practice, what quantities of useful and pleasant wines are mads in warm summers from these sources, and that at an easy expense. The fruit, indeed, cannot be expected to be uniformly ripe and excellent, but by far the largest part of the bunches are generally good, and fit for use; and those who have been most in the habit of the manufacture, and can afford to keep the wine by them for years in succession, well know that the improvement by melioration of time is sufficiently remarkable and cncouraging. As to the benevolent uses to which such wines may be occasionally applied among the poor and sickly of a neighbourhood, little need be said to recommend the practice. It is sufficient to say, that this species of useful benevolence is known to be excited by the cheapness and ease with which families in sufficient afluence become possessed of a moderate store by their own ceconomy and provident exertions. I would therefore subuit to you the propriety of our recommending a more general attention to this domestic object than our part of the nation seems to be acquainted with. The risk is small indeed; no land, useful for the purpose of agriculture, need be encumbered with it. The trial is easily made. The success may be at once pleasing and beneficial; and examples of such success, though gradual in their evidence, may become in process of time extensively and lastingly influential.

William Matrhews.

I shall now take the liberty of annexing a letter on the foregoing subject from an old and valuable correspondent, James Auderson, esq. LL.D. and F.R.S., in answer to one T 4 written 
written to him in the style of inquiry, his garden abounding with excellent wall-trained vines.

"DEAR SIR, Isleworth, Jan. 24, J $80 x$.

"I received your letter, some days ago, respecting the wines that may be made from the natural fruits of this country, which I should have sooner answerd, could I communicate any thing of the importance I wished; but that not being the case, I felt a grcat reluctance at the thought of troubling you with any thing not satisfactory.

"I can say little else than that, from our own experience for a short timc past, and what I have seen of others, I am perfectly satisfied that wine may be made from our native fruits;-red and white currants, gooseberries, black currants, raspberries, and other fruits, (with the help of sugar,) as good, and of as rich a flavour in all respects, as any that are imported from abroad. But the particulars in the process that may vary the qualities of the wine, where the materials are the same, are so numerous, and the time that must elapse before the result of any experiment can be known is so great, that I despair of living to sce any certainty established on this head. At present, I sometimes taste as good wine of that sort as could be desired, and again as bad as can be thought of, made by the same persons, when they can assign no reason for the difference. From our own limited practice I have been able to ascertain only two points that I think can be relied upon as tolerably well established: These are, first, that age, I mean not less than tbree years, is required to elapse before any wine that is to be really good can attain such excellence as to deserve the name of good; and second, that it never can attain that perfection il apirits of any kind be mixed with it. I apprebend that most of our made wines are greatly hurt by not adverting to these two circumstances.

"A Another circumstance that is, in my opinion, very necessary for the formation of good wine of this sort, is a certain degree of acidity in the fruit, without which the wine never acquires the zest which constitutes its peculiar excellence, but hurries forward too rapidly into the state of vine- 
gar. Currants at all times possess enongh of that acidity; but if gooseberries be too ripe they are apt to want it, and become insipidly sweet at an early period, though thoy soon become vinegar. It ought to be remarked, that the native acidity of the fruit is different from the acidity of vinegar, and possesses qualities extremely dissimilar. The sourness of vinegar, when it has once begun to be formed, continues to augment with age; but the native vegetable acid, when combined with saccharine matter, is gradually diminished as the fermentation proceeds, rill it is totally lost in the vinous zest into which both this and the sugar are completely converted before any vinegar is produced, if the fermentation be properly conducted.

"This, I believe, is a new opinion, which experience alone enabled me to adopt not very long ago. But I have had so niany experimental proofs of this fact, independent of the support it derives from reasoning, that I am satisfied it is well founded. I am satisfied further, that the wines of this country are debased chiefly by not adverting to it, and of which I think you will be convinced also by a moderate degree of attention.

is Every person knows that an insipid sweetness is the prevailing taste in liquors when they begin to ferment, and that it is gradually changed into a pungent vinosity as the process proceeds; but few persons have had occasion to remark that the native acid of fruit undergoes a similar change by the fermentatory process. Every one who tastes made wines, however, soon after the process has commenced, perceives that sour to a certain degree is mixed with the sweet. It chances, indeed, that the sweet is sooner blended than the sour; so that when the liquor is tasted a few months after it has been made, it hath lost some part of its sweetness, but still retains nearly' the whole of the sourness of the native acid of the fruit. And as the vinous flavour is yet but weak, the liquor appears to be thin and weak, and running into acidity. It is therefore feared, that if it be not then drank, it will soon run on to the state of vinegar; on this account it is often used in this state, when it forms a very insipid beverage. Frequently also, with a view to check the ace- 
tous process, and to give that degree of strength which will entitle it to the name of a cordial liquor, a certain portion of brandy is added to it, after which it may be kept for some time. The effect of this addition is to put a stop to that salutary process of fermentation which was going slowly forward, and gradually maturing the native vegetable acid into vinous liquor, which being at last blended with the saccharine vinous juice, produces that warm exhilarating fluid which cheers the heart and invigorates the strength of man. In this way, the sharp, insipid, and poor liquor which was first tasted, is, by a slow process, which requires a great length of time to complete it, converted into rich pleasant wine, possessing, in a great degree, that high zest which constitutes its principal excellence.

" My experience does not yet enable me to speak with certainty respecting all the circumstances that may affect the flavour, or augment or diminish the strength of wine, or accelerate or retard the time of its ripening. But my opinion at present is, that a great part of the flavour of wine depends considerably upon the skin of the fruit, which may be augmented or diminished by the degree of pressure the fruit is subjected to, and other particulars connected with it ; or by the macerating the fruit more or less in the juice before the skins be separated from the pulp; and that the ultimate qualities of the wine are considerably affected by the proportion of the original native acid of the fruit conjoined with the saccharine part of the juice. It seems to me very evident, also, that the saccharine juice can be more quickly brought into the state of wine than the acid portion of it, and that of course those wines that consist entirely of accharine matter, flavoured only by some pleasing vegetable perfume, such as cowslip or elder-flower wine, and others of similar sorts, may be sooner brought to be fit for drinking than those in which the juice of fruit form a considerable ingredient, and may be also made of a weaker and lighter quality. And that fruit wines, in proportion to the diminution of the quantity of fruit to that of sugar, or in proportion to the quantity of acid in the fruit, may be accelerated or retarded in the progress of fermentation; but that strong full-bodied wine, of good flavour, must have a considerable 
siderable proportion of native acid, and requires to be kept a long while before it can attain its ultimate perfection.

"I have had too little experience in the practice of making grape wine to enable me to speak with precision. The flavour of different kinds of grapes, we know, varies considcrably, which must affect the wine; but other circumstances in the process must affect it greatly. It is the only fruit known in this country that affords juice in abundance sufficient to admit of being made into wine witbout the addition of water, or rich enough without the use of sugar. Two years ago the season was so favourable that my grapes (the muscadine) ripened completely, and I determined to try to make some wine of them without either sugar or water. The juice was squeezed out by hand withont any other pressure, as I had no press. It fermented very well, and after a proper time it was tried. The liquor tasted sweetish, but wanted much of the vinous zest we wished for. This arose, I have no doubt, from the want of a due proportion of native acid, which would have been probably supplied by a complete pressure of the must, had I possessed the means of doing it; especially if the bunches of grapes had not been separated from the small foot-stalks to which the berries adhere. But not having a quantity sufficient to make it worth while to have a press, I thouglat of another method of attaining the end I aimed at, to which I was forced to resort : on finding that birds and vermin are so greedy of the grape, that it is a matter next to impossible to preserve them for any time here in quantities after they are ripe without being broken, which, by letting the juice flow out, lodges between the berries in the clusters, and which there becomes mouldy, and communicates a musty taste that cannot be gotten rid of.

"To avoid all those evils, I determined to gather the fruit when it is so far ripened only as just to begin to be pecked by the birds. As the juice possesses at that time more vegetable acidity and less of the saccharine taste than when fully ripe, I conceive that the wine made from it will be sharper and have a higher zest than the other; but dreading that the juice might not be sufficiently matured to do by itself, I added a portion of sugar and water to the juice, and 
have put it by for trial. It fermented well, and the liquor has at present as promising an appearance as I could wish. Should this mode of making grape wine succeed, it will be by far the cheapest wine we can make in this country; for the quantity of juice yielded by the grape is so much morc abundant, and so much richer thian that of our other fruits, and it is so much easier to be gathered and otherwise managed, that it must be much more desirable. The quantity of fruit produced, too, is so much greater when the vines are properly managed, than can be gotten from the same extent of ground of other fruits, as to give it a decided preference on the whole. I have just now in my cellar about forty gallons of that wine made from the grapes that were gathered from a wall of about fifteen yards in length, and fifteen feet high. Nor was that a crop above the average. Neither had that wine above half the quantity of sugar that other fruit wines would have required. I have no doubt that were vines raised from seeds of the best and earliest sorts, and carefully selected when they come to bear, we might thus obtain a grape that would ripen very well in this country without the assistance of a wall. It is by no means improbable that such a vine was once known in England.

" Next to the vine, I agree with you in thinking that the black currant is the best fruit we have of that kind for making wine. I have seen some of it that was truly excellent. It would be of great use for giving flavour to some other wines.

"W When I began this letter I thought that I had nothing to say; but being once begun, it has run on to an enormous length. I hope you will forgive me for it. I now speak little, and write less : and it requires an effort for me to begin with either; but, like a disorderly clock, when I am once fairly sel a-going, I run on perhaps without rhime or reason. Wishing you success in all your useful pursuits,

"I remain, dear sir,

"Your most humble servant,

To Mr. Matthews.

"James Anderson." 